\title{
Investigation of the Effect of Tarantula cubensis Extract on Acute Phase Response
}

\author{
Orhan Corum ${ }^{1}$, Ayse $\mathrm{Er}^{2}$ \& Burak Dik ${ }^{2}$
}

\begin{abstract}
Background: Tarantula cubensis alcoholic extract is used to accelerate wound healing and to relieve edema in many animal species. In addition, it may be useful for many infectious diseases. Considering to these effects, it is believe that these effects may be on immune system. Cytokines (tumor necrosis factor alpha, interleukin-1 beta, interleukin-6, interleukin-10 and interferon gamma) secreted by immune cells and acute phase proteins (haptoglobin, alpha 1 acid glycoprotein, serum amyloid A) secreted by liver play role in acute phase response. The aim of the present study was to determine the effect of Tarantula cubensis alcoholic extract on cytokine and acute phase protein levels in sheep.

Materials, Methods \& Results: Tarantula cubensis alcoholic extract ( $6 \mathrm{~mL} / \mathrm{sheep}$, subcutaneously, single dose) was administered to 6 healthy sheep. Blood samples were obtained before $(0 \mathrm{~h})$ and after treatments at 2, 4, 8, 12, 24 and $48 \mathrm{~h}$. Then, blood samples were centrifuged to obtain serum samples. Acute phase cytokines such as serum tumor necrosis factor alpha, interleukin-1 beta, interleukin-6, interleukin-10, interferon gamma and acute phase proteins such as haptoglobin, alpha 1 acid glycoprotein and serum amyloid-A concentrations were determined with commercially available kits on ELISA reader. Administration of Tarantula cubensis alcoholic extract caused fluctuations in tumor necrosis factor alpha, interleukin-1 beta, interleukin-6, interleukin-10, interferon gamma levels in sheep. In addition, levels of haptoglobin, alpha 1 acid glycoprotein, serum amyloid A showed fluctuations. But, these fluctuations in acute phase cytokines and acute phase proteins were not statistically significant $(P>0.05)$.

Discussion: Tarantula cubensis alcoholic extract, homeopathic medicine, is used trauma, retentio secundinarium, tendinitis, bluetongue, foot and mouth, metritis and arthritis in many animal species including sheep. Cytokines, secreted against various stimulus including infectious diseases, play role in wound healing and in the regulation of the immune system. In current study, administration of Tarantula cubensis alcoholic extract lead to fluctuations in tumor necrosis factor alpha, interleukin-1 beta, interleukin-6, interleukin-10 and interferon gamma levels, but these changes were not statistically significant $(P>0.05)$. Non-statistical fluctuations in cytokines result from inadequate immunological response of sheep against to Tarantula cubensis alcoholic extract. Also, use of molecular analysis techniques may be changed these results. Acute phase proteins are significantly secreted from the liver during the acute phase response. In current study, administration of Tarantula cubensis alcoholic extract in sheep caused non-statistifical fluctuations on haptoglobin, alpha 1 acid glycoprotein and serum amyloid A levels $(P>0.05)$. Tumor necrosis factor alpha and interleukin-1 beta stimulate synthesis of interleukin-6. Interleukin-6 provides synthesis of acute phase proteins in liver. Non-statistical fluctuations in acute phase proteins result from inadequate stimulus of IL-6. In conclusion, it may be stated that administration of Tarantula cubensis alcoholic extract has no distinctive effect on the acute phase response. However, when Tarantula cubensis alcoholic extract is administered repeated times or other acute phase parameters are evaluated, different results may be observed.
\end{abstract}

Keywords: sheep, Tarantula cubensis alcoholic extract, cytokines, acute phase proteins. 


\section{INTRODUCTION}

Theranekron D6 is veterinary product and includes Tarantula cubensis alcoholic extract (TCAE). It is prepared from the spider Tarantula cubensis. In veterinary medicine, TCAE is often used as demarcation provider, epithelialization accelerator and edema relieving effects in traumatic or necrotic disorders and various infectious diseases [2].

Cytokines are soluble glycoproteins. They play role in immune system regulation, inflammatory response, cell division/differentiation, wound healing and hematopoiesis $[3,11,16]$. Proteins changed significantly in the blood levels as the immune system's response at early (acute) period in cases such as infection, inflammation, trauma and stress are given acute phase proteins name. In particular, they are synthesized by interleukin (IL)- 6 in the liver and developing response takes 1-2 days. Essential tasks are return to live normal function, to limit microbial growth and to regulate hemostasis as well as many biological effects. Haptoglobin, alpha 1 acid glycoprotein (A1AG) and serum amyloid A (SAA) are acute phase proteins and increases in inflammation $[4,9,18,21]$.

Cytokines and acute phase proteins are necessary for the functionality of immune system and concentrations of these rise within hours of blood concentrations in infection $[3,9,19,21]$. It has been hypothesized that cytokines and acute phase proteins have been increased by TCAE.

The main objective of this study was to determine the effect of single dose TCAE on tumor necrosis factor alpha (TNF $\alpha$ ), IL-1 beta, IL-6, IL-10, interferon gamma (IFN $\gamma$ ), haptoglobin, A1AG and SAA levels in sheep.

\section{MATERIALS AND METHODS}

\section{Animals}

Totally 6 healthy Akkaraman sheep (aged >2 years, weight $45-60 \mathrm{~kg}$ ) were used in this study.

\section{Experimental procedure}

TCAE (Theranekron D6 ${ }^{\circledR}$ Enj. Sol. $)^{1}$ was administered with sucutaneously single dose $(6 \mathrm{~mL})$ in sheep. Blood samples were collected from $V$. jugularis before ( $0 \mathrm{~h}$, control) and 2, 4, 8, 12, 24 and $48 \mathrm{~h}$ after administration and centrifuged to obtain serum samples.

\section{Measurements}

The levels of serum TNF $\alpha$ (Sheep TNF $\alpha$ ELISA kit) ${ }^{2}$, IL- $1 \beta$ (Sheep IL-1 $\beta$ ELISA kit) ${ }^{2}$, IL-6 (Sheep IL-6 ELISA kit) ${ }^{2}$, IL-10 (Sheep IL-10 ELISA kit $)^{2}$, IFN $\gamma$ (Sheep IFN $\gamma$ ELISA kit $)^{2}$, haptoglobin (Sheep Hpt/HP ELISA kit) $)^{2}$ A1AG (Sheep $\alpha$ 1-AGP ELISA kit) $^{2}$ and SAA (Sheep SAA ELISA kit) ${ }^{2}$ were determined with ELISA reader (MWGt Lambda Scan $200)^{3}$.

\section{Statistical analysis}

The data were evaluated by ANOVA and Tukey post hoc test (SPSS 19.0). $P<0.05$ was considered as statistically significant difference.

\section{RESULTS}

After administration of TCAE, serum TNF $\alpha$, IL-1 $\beta$, IL-6, IL-10, IFN $\gamma$, haptoglobulin, A1AG and SAA levels were showed in Figures 1, 2, 3, 4, 5, 6, 7 and 8, respectively. Both cytokine levels and acute phase protein levels were determined not statistically change $(P>0.05)$.

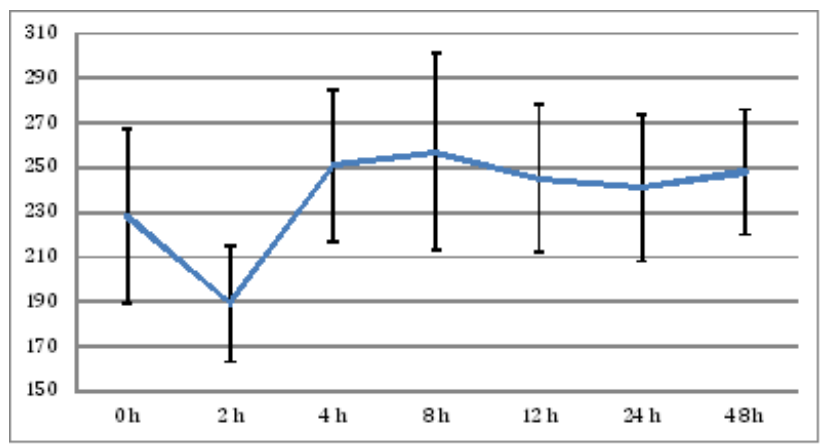

Figure 1. Effect of TCAE on serum tumor necrosis factor alpha (TNF $\alpha$; $\mathrm{ng} / \mathrm{L})$ level $(P>0.05)$.

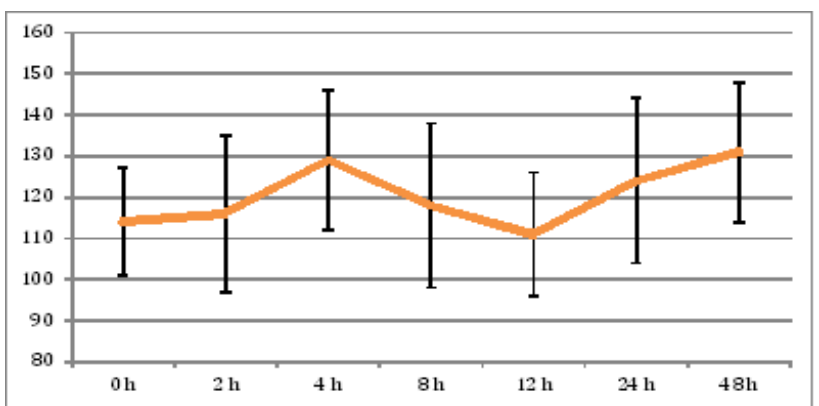

Figure 2. Effect of TCAE on serum interleukin-1 beta (IL-1 $\beta ; p g / L)$ level $(P>0.05)$. 


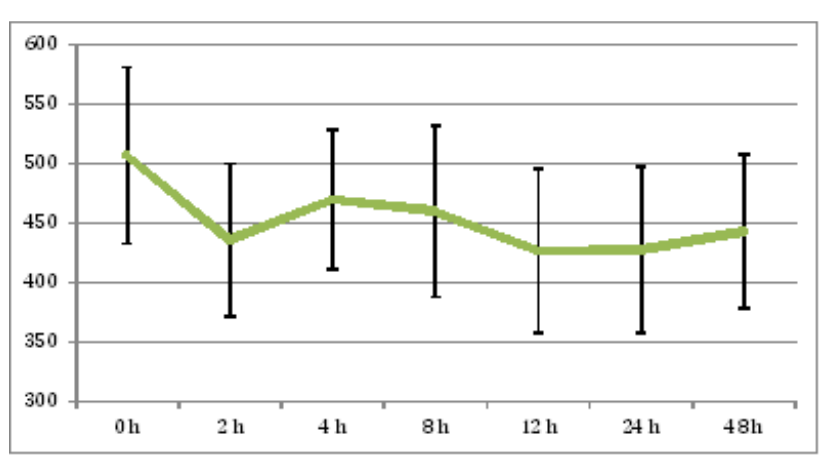

Figure 3. Effect of TCAE on serum interleukin-6 (IL-6; ng/L) level ( $P$ $>0.05)$.

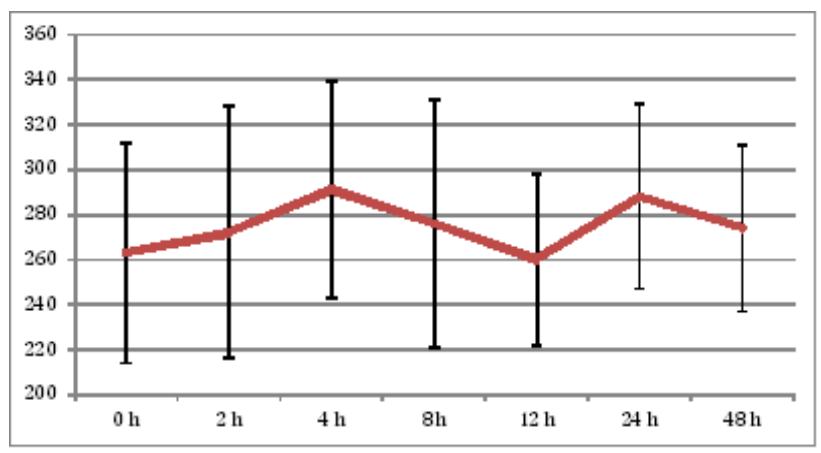

Figure 5. Effect of TCAE on serum interferon gamma (IFN $\gamma ; \mathrm{pg} / \mathrm{mL}$ ) level $(P>0.05)$.

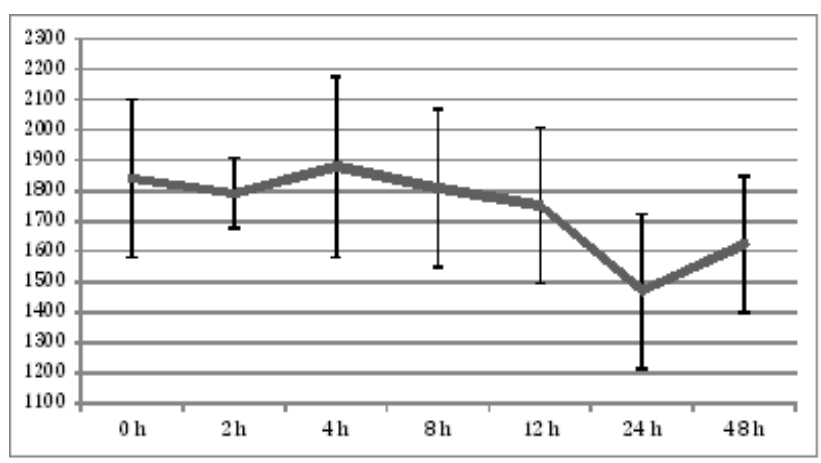

Figure 7. Effect of TCAE on serum alpha 1 acid glycoprotein (A1AG; $\mathrm{mg} / \mathrm{L})$ level $(P>0.05)$.

\section{DISCUSSION}

TCAE is evaluated a homeopathic medicine in the veterinary field and recommended in many animal species, including sheep. Product is used primarily as demarcation provider, epithelialization accelerator and edema relief in necrotic or traumatic situations. In addition, it is used in infectious diseases and cancer $[1,2,5]$. It is stated that the absence of significant side effects of TCAE in sheep or horse $[6,15]$.

Cytokines are secreted especially immune cells against various warnings including infectious diseases,

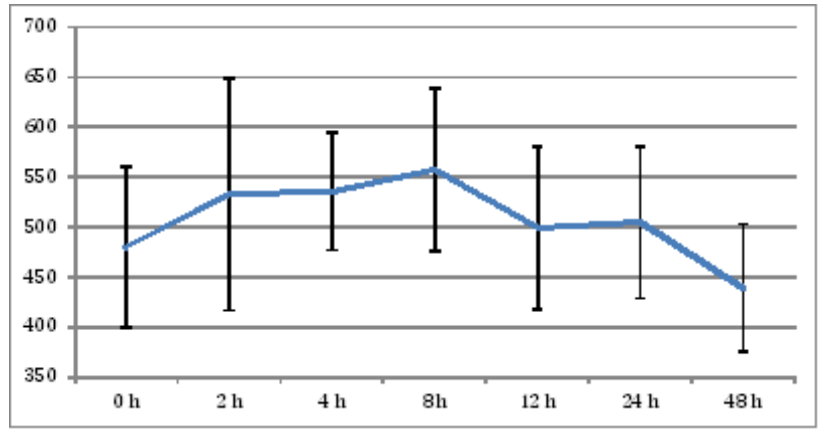

Figure 4. Effect of TCAE on serum interleukin-10 (IL-10; pg/mL) level $(P>0.05)$.

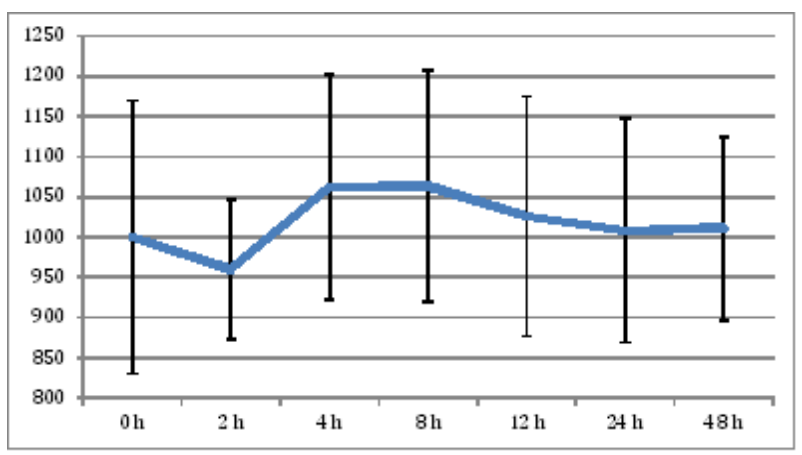

Figure 6. Effect of TCAE on serum haptaglobulin $(\mu \mathrm{g} / \mathrm{mL})$ level $(P>$ $0.05)$.

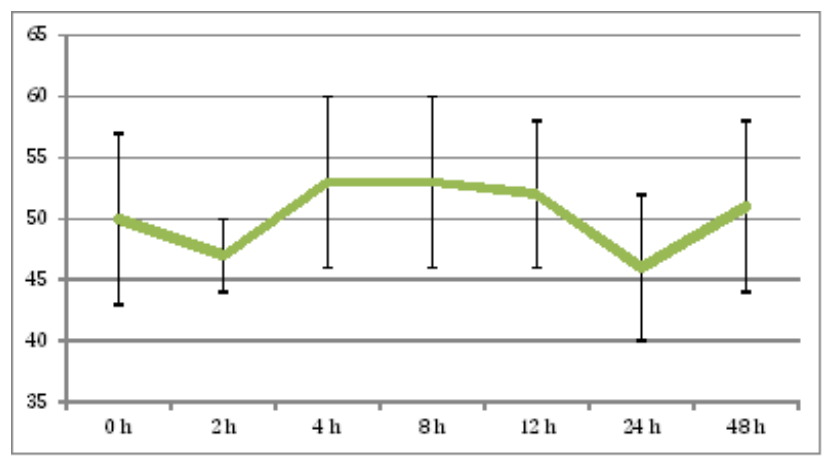

Figure 8. Effect of TCAE on serum amyloid A (SAA; $\mu \mathrm{g} / \mathrm{mL})$ level $(P$ $>0.05$ ).

and play role involved in wound healing and regulation of the immune system $[11,16]$.

It has been reported that TCAE application have beneficial effects in various diseases (such as blue tongue, foot and mouth disease, endometritis, footrot), traumatic tissue ruptures, papillomatous, oral ulcer and cancer in clinical trials $[1,5,7,8,10,12,13,17,20]$. In current study, administration of TCAE in sheep caused fluctations in TNF $\alpha$ (Figure 1), IL-1 $\beta$ (Figure 2), IL-6 (Figure 3), IL-10 (Figure 4) and IFN $\gamma$ (Figure 5) levels, but this fluctuations not statistically significant $(P>0.05)$. 
IL-6 allows the synthesis of acute phase protein from liver. Synthesis of IL- 6 has stimulated by TNF $\alpha$ and IL-1 $[14,19]$. A significant effect on the measured cytokines can not be seen due to not enough immunological response to the TCAE application or not be researched with molecular techniques.

As with changes in levels of cytokines, acute phase proteins levels not determined statistically change. This state can result from the not enough stimulation of the synthesis IL- 6 by TCAE, because IL-6 starts acute phase proteins synthesis from liver.

\section{CONCLUSION}

In conclusion, it may be stated that TCAE application has no distinctive effect on the acute phase cytokines or proteins. However, when TCAE is administered repeated times or other acute phase parameters are evaluated, different results may be observed

\section{MANUFACTURERS}

${ }^{1}$ Richter Pharma AG. Wels, Austria.

${ }^{2}$ Shanghai Sunred Biological Technology. Shangai, China.

${ }^{3}$ Bio-Tek Instruments. Winooski, VT, USA.

Funding. This study was supported by SUBAK (15401030).

Ethical approval. The study protocol was approved by Ethical Committee of Faculty of Veterinary Medicine, Selcuk University, Turkey (No.2014/27).

Declaration of interest. The authors report no conflicts of interest. The authors alone are responsible for the content and writing of the paper.

\section{REFERENCES}

1 Albay M.K., Sahinduran S., Kale M., Karakurum M.C. \& Sezer K. 2010. Influence of Tarantula cubensis extract on the treatment of the oral lesions in cattle with bluetongue disease. The Journal of The Faculty of Veterinary Medicine University of Kafkas. 16(4): 593-596.

2 Anonymus. 2015. Theranekron D6. Richter Pharma. Available at: http://www.richter-pharma.at/product-theranekrond6_301.htm. [Accessed online in October 2015].

3 Baykal Y., Karaayvaz M. \& Kutlu M. 1998. Interleukins. Turkiye Klinikleri Journal of Medical Sciences. 18(2): 77-84.

4 Coskun A. \& Sen I. 2011. Clinical Use of Acute Phase Proteins in Cattle. Journal of Health Sciences. 20(3): 240-246.

5 Calıskan G.U., Cecen G. \& Gorgul O.S. 2007. Perianal Tear Caused by Cornual Stroke in a Pregnant Heifer. Veteriner Cerrahi Dergisi. 13(1): 31-4.

6 Dik B., Er A. \& Corum O. 2014. Effect of alcoholic extract of Tarantula cubensis (Theranekron ${ }^{\circledR}$ ) on serum thiobarbituric acid-reactive species concentrations in sheep. Eurasian Journal of Veterinary Sciences. 30(2): 68-71.

7 Dolapcioglu K., Dogruer G., Ozsoy S., Ergun Y., Ciftci S., Karapinar O.S. \& Aslan E. 2013. Theranekron for treatment of endometriosis in a rat model compared with medroxyprogesterone acetate and leuprolide acetate. European Journal of Obstetrics \& Gynecology and Reproductive Biology. 170(1): 206-210.

8 Duz E., Icen H., Arserrim N.B., Cakmak F., Bakir B. \& Uysal E. 2012. Comparison of Classic, Theranekron and Classic-Plus Theranekron Treatment on the Foot and Mouth Disease Lesions in Cattle in Van, Diyarbakir and Ankara Regions in Turkey. Journal of Animal and Veterinary Advances. 11(18): 3258-3261.

9 Gokce H.I. \& Bozukluhan K. 2009. Important Acute Phase Proteins in Farm Animals and their Usage in Veterinary Practice. Dicle Üniversitesi Veteriner Fakültesi Dergisi. 1 (1): 1 - 14.

10 Gultiken N. \& Vural M. 2007. The effect of Tarantula cubensis extract applied in pre and postoperative period of canine mammary tumours. JIVS. 2: 13-23.

11 Gunes H. 1999. Effects of Cytokines on Cell Cycle. Turkish Journal of Biology. 23: 283-292.

12 Icen H., Sekin S., Simsek A., Kochan A. \& Tunik S. 2011. The efficacy of Tarantula cubensis extract (Theranekron) in treatment of canine oral papillomatozis. Asian Journal of Animal and Veterinary Advances. 6(7): 744-749.

13 Lotfollahzadeh S., Alizadeh M.R., Mohri M. \& Mokhber Dezfouli M.R. 2012. The therapeutic effect of Tarantula cubensis extract (Theranekron(R)) in foot-and-mouth disease in cattle: a randomised trial in an endemic setting. Homeopathy. 101(3): 159-164.

14 Paradkar P.H., Joshi J.V., Mertia P.N., Agashe S.V. \& Vaidya R.A. 2014. Role of cytokines in genesis, progression and prognosis of cervical cancer. Asian Pacific Journal of Cancer Prevention. 15(9): 3851-3864.

15 Sardari K., Mohri M., Sabzevari S. \& Fathi B. 2011. Effects of the Theranekron ${ }^{\circledR}$ an alcoholic extract of the Tarantula cubensis on hematology and serum biochemical properties in horses. Iranian Journal of Veterinary Science and Technology. 3(2): 9-16. 
16 Sasi W., Sharma A.K. \& Mokbel K. 2014. The role of suppressors of cytokine signalling in human neoplasms. Molecular Biology International. 2014: 630797.

17 Sertkaya H. \& Sindak N. 2004. Incidence and Treatment With Two Different Drug Combinations of Sheep's Footrot in Birecik District of Sanliurfa and its Villages. Veteriner Cerrahi Dergisi. 10(1-2): 48-54.

18 Sevgisunar N.S. \& Sahinduran S. 2014. Acute Phase Proteins, Purpose of Uses and Clinical Importance in Animals. Mehmet Akif Ersoy Üniversitesi Sağllk Bilimleri Enstitüsü Dergisi. 2(1): 50-72.

19 Tuglu C. \& Kara S. 2003. Depression, cytokines and immune system. Bulletin of Clinical Psychopharmacology. 13: 142-50.

20 Yardımcı C. \& Yardımcı B. 2008. Indolent ulcer in a cat. Ankara Üniversitesi Veteriner Fakültesi Dergisi. 55: 65-67.

21 Yucel A.E. 2004. Clinical Significance of C-Reactive Protein and Other Acute Phase Proteins. Türkiye Tıp Dergisi. 11(1): 42-52. 